\title{
Epidemiological Investigation of Cattle Abortion and Its Association with Brucellosis in Jimma Zone, Ethiopia
}

This article was published in the following Dove Press journal: Veterinary Medicine: Research and Reports

\author{
Benti Deresa' \\ Dereje Tulu ${ }^{2}$ \\ Feyissa Begna Deressa (iD) \\ 'School of Veterinary Medicine, College \\ of Agriculture and Veterinary Medicine, \\ Jimma University, Jimma, Ethiopia; \\ ${ }^{2}$ Ethiopian Institute of Agricultural \\ Research, Tepi Agricultural Research \\ Center, Tepi, Ethiopia
}

Background: The epidemiology of cattle abortion and its association with brucellosis is not well understood in Ethiopia. Therefore, the aim of this study was to determine the magnitude, associated risk factors of abortion, and its association with brucellosis in cattle of Jimma zone, Ethiopia.

Methods: A cross-sectional study was carried out from October 2018 to October 2019 in Jimma zone. A total of 484 pregnant cattle were randomly selected from two districts based on the composition of the cattle population. Besides, blood samples were collected from a total of 484 randomly selected cattle to assess the presence of Brucella antibody. The presence of an antibody against Brucella organism was first tested by the Rose Bengal Plate test, and then positive serum was confirmed using the complement fixation test.

Results: An overall $14.30 \%$ cumulative incidence rate of abortion was recorded in study areas. In this study, breed, herd size, method of breeding, previous history of abortion, accessibility of dog to cattle and season were identified as risk factors for the occurrence of cattle abortion. Higher cumulative incidence of abortion (31.82\%) was observed in Brucella antibody positive cattle than those of antibody negative cattle $(13.42 \%)$. However, the difference noted was not statistically significant $(P<0.05)$.

Conclusion: It is important to create awareness about the impact of the abortion on cattle production and the applicable control technique of abortion should be aimed and implemented. Moreover, further investigation should be conducted to identify the specific cause of abortion and the associated loss in the study areas.

Keywords: abortion, cumulative incidence, risk factors, brucellosis, cattle, Ethiopia

\section{Introduction}

Ethiopia has a huge livestock population, with a total cattle population of 59.5 million. Out of these cattle, $55.5 \%$ were female cattle and $44.5 \%$ were male cattle. ${ }^{1}$ Ethiopia has paid more attention to increasing cattle productivity (meat and milk) through breeding and health interventions. ${ }^{2,3}$ Cross-breeding programs have been used as the main strategies to raise milk production in the country. ${ }^{4}$ Ethiopia has given priority on the improvement of dairying at farmer level to extend the provision of milk from smallholder dairy farms. ${ }^{5,6}$ However, reproductive disorder has become a major obstacle to this development plan. Among these, abortion was the main constraint for this development to achieve its goal. ${ }^{7,8}$ Abortion is defined as the premature expulsion of the fetus between 42 days and approximately 260 days of gestation. ${ }^{9}$ A sudden and dramatic increase of abortion in the herd over a long time is more commonly seen. ${ }^{10}$
Correspondence: Dereje Tulu Ethiopian Institute of Agricultural Research, Tepi Agricultural Research Center, P. O. Box 34, Tepi, Ethiopia Email derejetulu5@gmail.com
Veterinary Medicine: Research and Reports 2020:II 87-98 
Several infectious agents such as virus, bacteria, protozoa, and fungus are accountable for cattle abortion. ${ }^{11}$ Abortion is also caused by non-infectious included toxic substances, nutritional, metabolic, and physical insults. ${ }^{12}$ Some of the infectious agents, such as Brucella abortus, Coxiella burnetii, Leptospira, and Listeria monocytogenes that are responsible for abortion in cattle have also zoonosis implication. Among the infectious causes of abortion, Brucella infection is one of the foremost causes of abortion in cattle. ${ }^{13}$ Moreover, Brucella infection continues to cause higher economic losses and public health concerns in the world. ${ }^{14,15}$ Brucellosis in cattle is mainly caused by Brucella abortus and sporadically by $B$. melitensis and B. suis. Brucellosis is mainly characterized by causing an abortion in late pregnancy, retained fetal membrane, and infertility in cattle. ${ }^{16}$

The likelihoods of abortion may differ between herds, calving seasons, parity, pregnancy stage, and milk yield. Likewise, the prevalence of previous abortion may increase the risk of abortion in cattle. ${ }^{17}$ Abortion is a major problem for dairy producers in Ethiopia, like in many other countries. ${ }^{12}$ In addition to the loss of fetus, abortion imposes rebreeding cost, veterinary care, decreased milk yield, premature culling, and replacement cost to farmers. ${ }^{9,18,19}$ Several studies on reproductive disorder have been conducted on local and cross-breed cattle in different agro-ecological and production systems in Ethiopia. These results indicated that cattle abortion is a common reproductive disorder with different prevalences. ${ }^{8,12,20}$ The highest prevalence of abortion (28.9\%) was observed by Siyoum et $\mathrm{al}^{21}$ in west Shewa. On the other hand, Gizaw et $\mathrm{al}^{22}$ reported a relatively lower abortion prevalence (2.2\%) in central Ethiopia. An incidence of abortion of more than $2-5 \%$ should be viewed seriously, and efforts should be made to determine the associated risk factors and causes, and measures should be taken to control it. ${ }^{23}$ Currently, the different studies indicate that brucellosis is still a widespread disease, causing huge economic loss due to abortion. ${ }^{24-26}$

Limited reports are available that determine the magnitude, associated risk factors of abortion, and its association with brucellosis in cattle. This study helps to make interventions aimed at reducing the impacts of abortion on cattle production. Therefore, the aim of study was to investigate the magnitude, associated risk factors of abortion, and its association with brucellosis in cattle of Jimma zone, Ethiopia.

\section{Materials and Methods}

\section{Study Areas}

The study was conducted in two selected districts of Jimma zone, namely Limu Seka and Chora Boter. Limu Seka district is located at an altitude of 1400-2200 meters above sea level, $09^{\circ} 29^{\prime}$ North latitude and $37^{\circ} 26^{\prime}$ East longitudes. The agroecology is characterized by $13 \%$ highland and $55 \%$ midhighland and $32 \%$ lowland. The average temperature varies from a minimum $15.1^{\circ} \mathrm{C}$ to a maximum $31^{\circ} \mathrm{C}$. There are two distinct seasons in Limu Seka: the rainy season (from late March to October), and the dry season (November to early March). The rainfall is often more than $1800 \mathrm{~mm}$ per annum. Limu Seka district has 295,627 head of cattle, 104,892 head of sheep, 89,079 head of goats, and 134,370 human populations. Chora Boter district is located at $9^{\circ}-10^{\circ} 24^{\prime}$ North latitude and $37^{\circ} 56^{\prime}-40^{\circ} 35^{\prime}$ East longitude with an altitude range of 1100-2200 meters above sea level. The agroecology is characterized by $25 \%$ highland, $73.5 \%$ mid-highland, and $2.3 \%$ lowland. The annual average temperature ranges from $18.3^{\circ} \mathrm{C}$ to $26.7^{\circ} \mathrm{C}$. Similar to Limu seka district, the district has two seasons. The rainfall is often more than 1800-2200 mm per annum. Chora Boter district has 228,846 head of cattle, 47,854 head of sheep, 68,037 head of goats, and 215,348 human populations. In both districts, local cattle breed is the most dominant one followed by some crosses of Holstein-Friesian. The management systems of the study area are an extensive (crop-livestock production) system and semi-intensive (urban production) system (Figure 1).

\section{Study Population and Design}

All pregnant cattle in selected districts of Jimma zone were the target population in this study. The target population was the entire group of pregnant cattle, to which the researcher wishes to generalize the study findings for this study. The study population was pregnant cattle 3 years age and above in selected peasant associations. Pregnant cattle included in this study were study units. A cross-sectional study was conducted from October 2018 to October 2019 in selected districts of Jimma zone. This study aimed to determine the magnitude, associated risk factors of abortion, and its association with brucellosis in cattle.

\section{Sampling Procedure and Sample Size Determination}

Jimma zone was selected purposively based on the history of abortion, while districts, peasant associations (PA), villages, and herds were selected randomly. A multistage 


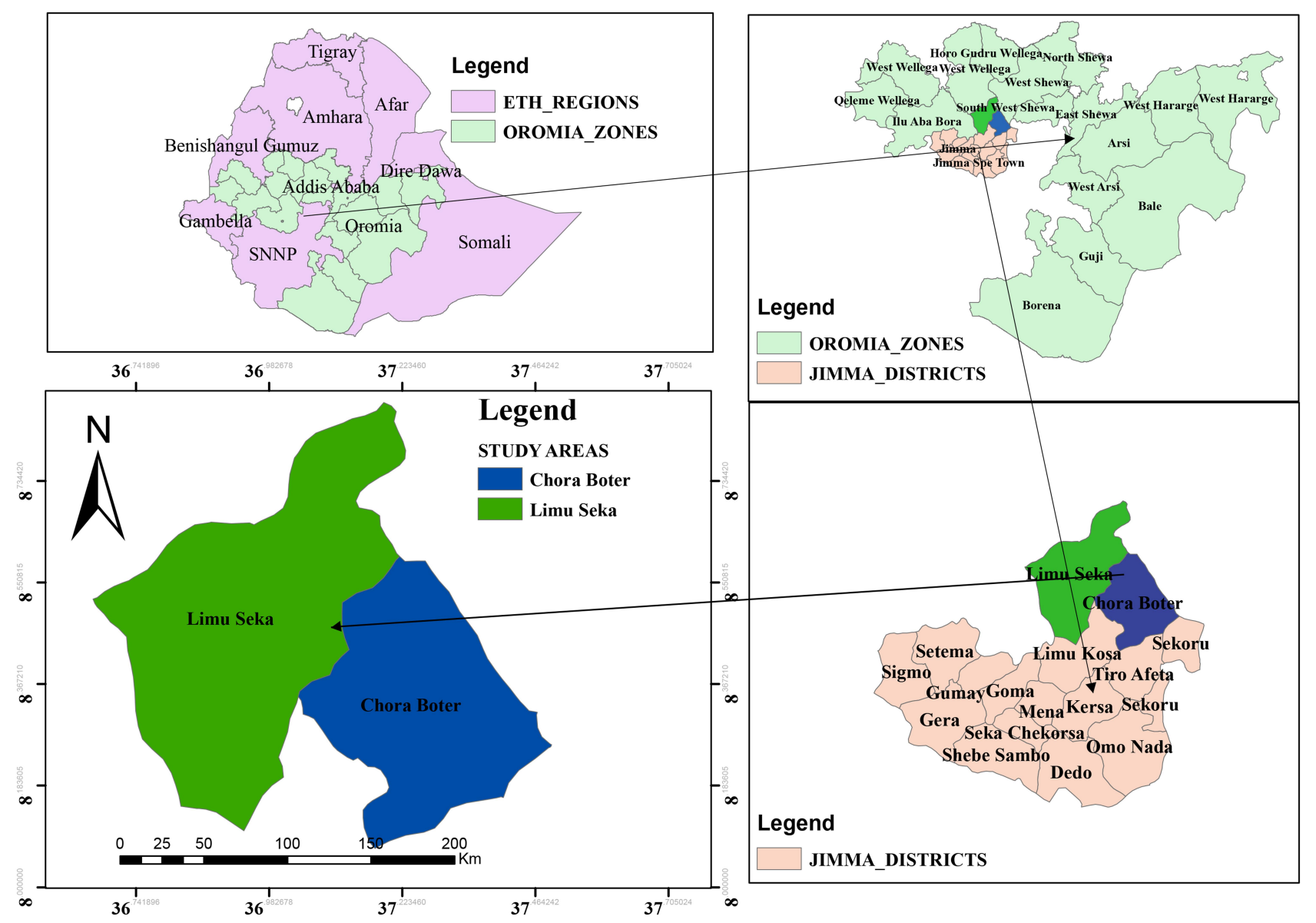

Figure I Map of study areas (Limu Seka, and Chora Boter districts).

sampling method was conducted to selected cattle from different herds. Six and four PAs were sampled from Limu Seka and Chora Boter districts, respectively, based on the number of PAs and cattle populations. A total of 30 villages were selected from those peasant associations by simple random sampling method based on the number of the villages in those peasant associations. Similarly, a total of 142 herds were selected randomly from those villages. The criteria for selection of the herds were an accurate recording system. The herds studied were under a similar management practice, namely receiving regular veterinary service. The pregnant cattle were selected randomly using a lottery method from herd through rectal palpation based on the composition of cattle population. The sampling frame of pregnant cattle was taken from respective peasant associations. Since no study was done on cattle abortion and its association with brucellosis in study areas, the sample size required for this study was computed by considering $95 \% \mathrm{CI}, 5 \%$ precision, and $50 \%$ expected prevalence according to a formula given by Thrusfield. ${ }^{27}$ Hence, the number of cattle needed to demonstrate the cumulative incidence of abortion was 384 pregnant cattle; however 484 pregnant cattle were examined to increase the accuracy of the result.

\section{Case Definition}

Abortion was defined as any loss of pregnancy of cattle confirmed pregnant in the period between 45 and 260 days of gestation. Detection, diagnoses, and subsequent abortion recordings were made by a veterinarian. An expelled fetus or fetal membrane when the cow was observed in estrus and examination verified that there was an abortion and the cow was found to be non-pregnant on a follow-up examination. The reason for considering this period is that around 42 days of gestation the placenta would be completed and the fetus is dependent on its mother through the placenta. Trimesters of pregnancy were first for 46 to 90 days, second for 91 to 180 days, and third for 181 to 260 days of gestation, respectively. In the data set abortion was 
coded as a binomial variable $(0=$ abortion and $1=$ no abortion), indicating whether or not a cow aborted.

\section{Data Collection}

From a total of 484 pregnant cattle the data were collected. Information such as the gestation stage of abortion (first trimester, second trimester, and third trimester), the pattern of abortion occurrence, and factors related to individual cattle such as age, breed, parity, and previous history of abortion, were documented. Beside, management and environmental-related factors such as herd size, type of breeding used, management system, contact of cattle with dogs, introduction of new cattle, calving season, agroecology, and origin (district) of the cattle were also recorded. The management system was grouped as extensive and semi-intensive according to Richard. ${ }^{28}$ Similarly, cattle were categorized as 3-6 and greater than 6 years of age, since the age at first calving of cattle in tropical conditions was estimated to be 24-36 months. ${ }^{29}$ Herd size was categorized into small (3-5 heads of cattle), medium (6-10 heads of cattle), and large ( $>10$ heads of cattle). Those cattle that were housed in the same barns were grouped together and considered as one herd. ${ }^{30,31}$ Parity number was categorized as monoparous (parity one) and pluriparous ( $\geq$ two parities). ${ }^{32,33}$

\section{Serological Tests}

About $10 \mathrm{~mL}$ of blood samples were collected from the jugular vein of each animal by using a sterile needle and plain vacutainer tube. Identification numbers of each animal was labeled on the corresponding vacutainer tube and blood samples were allowed to stand overnight at room temperature to get the serum. The cattle codes were transferred to the cryovials to which the serum was decanted and serum samples were kept at $-20{ }^{\circ} \mathrm{C}^{14}$ in Jimma University microbiology laboratory until they were transported to the National Veterinary Institute (NVI) using icebox for serological tests. The sera samples were screened for antibodies against Brucella organism using the Rose Bengal Plate Test (RBPT) as the technique suggested by OIE. ${ }^{34}$ The serum samples and antigens were taken from the refrigerator and then stayed at room temperature for half an hour and processed following the recommended procedure. The interpretation of both positive and negative control results was done according to the degree of agglutination, and reaction was read in a good light source or a magnifying glass when microagglutination was suspected. The RBPT results were interpreted 0 ,
,+++ , and +++ , as has been described by Dohoo et al, ${ }^{35}$ where 0 indicated no agglutination, + indicated barely visible agglutination (using magnifying glass), ++ indicated fine agglutination, and +++ indicates coarse clumping. Those serums identified with no agglutination (0) were regarded as negative, while those with,+++ , and + ++ were considered as positive.

All positive sera for RBPT were confirmed using complement fixation test (CFT) by Brucella Abortus antigen S99. The antigen dilution was standardized at 1:10. Twofold dilutions $(1: 5,1: 10,1: 20$, and 1:40) of test sera were ready in standard 96-well U-bottom microliters plates before adding Brucella antigen, guinea pigs complement, and 3\% sensitized sheep red blood cells. The reagent was prepared and evaluated by titration following the protocols of OIE. ${ }^{14}$ The plates were incubated at $37^{\circ} \mathrm{C}$ for $30 \mathrm{~min}$ utes with agitation and results were read after the plates have been centrifuged at $2500 \mathrm{rpm}$ for 5 minutes at $4{ }^{\circ} \mathrm{C}$. Sera with a strong reaction more than $75 \%$ fixation of complement $(3+)$ at $1: 5$ dilution or at least with $50 \%$ complement fixation (2+) at 1:10 dilution and above were considered as positive and lack of fixation/complete hemolysis were considered as negative. ${ }^{34}$ A cattle was considered positive if test seropositive on both RBPT and CFT in serial interpretation. The combination of RBPT and CFT in serial most widely used is commonly recommended to maximize the specificity of the test result by ruling out false-positive serological cross-reactions. ${ }^{35}$

\section{Data Management and Analysis}

All host, management, and environment factors believed to be associated with epidemiology of cattle abortion were recorded in a Microsoft Excel ${ }^{\circledR}$ spreadsheet. The collected data were analysis with STATA version 11.0 for Windows (Stata Corp. College Station, TX, USA). Binary and multivariable regression analyses were conducted using abortion (yes or no) as dependent variable. Age (3-6 years, $>6$ years), breed (local, cross of Holstein-Friesian), parity (monoparous, pluriparous), and previous history of abortion (yes, no) were entered in the model as independent variables. Moreover, district (Limu Seka, Chora Boter), agro-ecology (mid-land, lowland), herd size (small herd 3-5 heads, medium herd 6-10 heads, large herd $>10$ heads), management system (semi-intensive, extensive), type of breeding used (natural, artificial insemination), contact of cow with dog (yes, no), introduction of new animals (yes, no), seasons (autumn, summer, spring, winter), and status of brucellosis (positive, negative) were also entered in the model as independent 
variables. Brucella seropositive cattle were defined as any cattle with both RBPT and CFT positive. The cumulative incidence of abortion as a percentage was calculated as the number of cattle aborted during the study period divided by the total number of pregnant cattle available during the period. For each prevalence binomial exact $95 \%$ confidence interval (CI) was calculated using Epitool. Association between abortion (dependent variable) and presumptive risk factors (independent variables) were investigated by using the logistic regression model. Univariable logistic regression analysis was used to select individual independent variables that may predict individual aborted cattle. The independent variable with $P \leq 0.25$ at the univariable after being checked for multicollinearity using collinear matrix index and interaction effect using cross-product terms were taken to be multivariable modeling. The variables with $P \leq 0.05$ were retained in the final model. The backward elimination procedure was used to eliminate the factors that were not significant at $P<0.05$ in the overall model. The model fitness was observed by using Hosmer-Lemeshow test. In analysis, a covariate was considered a confounder and included in the model if its inclusion altered the OR of the estimated risk by more than $20 \% .{ }^{35}$ For all the analyses, confidence level (CL) is at $95 \%$ and $P \leq 0.05$ was set for significance.

\section{Results}

Of the 484 pregnant cattle examined in this study, $14.30 \%$ (95\% CI $=11.1-17.4)$ of them had an abortion problem. The highest $(21.80 \%)$ and lowest $(9.10 \%)$ cumulative incidence of abortion were recorded in Dame and

Table I Distribution of Cumulative Incidence of Abortion in Cattle of Study Areas

\begin{tabular}{|l|l|l|l|}
\hline PA & $\begin{array}{l}\text { Total } \\
\text { Cattle } \\
\text { Examined }\end{array}$ & $\begin{array}{l}\text { Total } \\
\text { Cattle } \\
\text { Aborted }\end{array}$ & $\begin{array}{l}\text { Cumulative } \\
\text { Incidence (\%) (95\% } \\
\text { Cl) }\end{array}$ \\
\hline Atinago & 51 & 8 & $15.70(8.2-28.0)$ \\
Dame & 55 & 12 & $21.80(13.0-34.4)$ \\
Deneba & 53 & 5 & $9.40(4.1-20.3)$ \\
Cheka & 49 & 5 & $10.20(4.4-21.8)$ \\
Doora & 47 & 7 & $14.90(7.4-27.7)$ \\
Bontu & 46 & 6 & $13.00(6.1-25.7)$ \\
Mecha Dire & 48 & 5 & $10.40(4.5-22.2)$ \\
Chora Bage & 44 & 9 & $20.50(11.2-34.5)$ \\
Soyoma & 44 & 4 & $9.10(3.6-21.2)$ \\
Kobi & 47 & 8 & $17.0(8.9-30.1)$ \\
Overall & 484 & 69 & $14.30(11.1-17.4)$ \\
\hline
\end{tabular}

Abbreviations: $\mathrm{Cl}$, confidence interval; PA, peasant association.
Table 2 Cumulative Incidence of Abortion Based on Stages of Pregnancy in Cattle

\begin{tabular}{|l|l|l|l|}
\hline $\begin{array}{l}\text { Stages of } \\
\text { Gestation }\end{array}$ & $\begin{array}{l}\text { Number of } \\
\text { Aborted } \\
\text { Cows }\end{array}$ & $\begin{array}{l}\text { Cumulative } \\
\text { Incidence (\%) }\end{array}$ & $\mathbf{9 5 \% ~ C l}$ \\
\hline First trimester & 4 & 5.80 & $0.3-11.3$ \\
Second trimester & 22 & 31.90 & $20.9-42.9$ \\
Third trimester & 43 & 62.30 & $50.9-73.8$ \\
Overall & 69 & 100.00 & \\
\hline
\end{tabular}

Abbreviation: $\mathrm{Cl}$, confidence interval.

Soyoma areas (Table 1). The highest cumulative incidence of abortion was observed in the third trimester $(62.30 \%)$ followed by the second trimester (31.90\%), and the lowest in the first trimester $(5.80 \%)$, as described in Table 2. According to the month of the year, the lowest cumulative incidence of abortion in cattle was observed in November and it has tended to remain until March. The rate began to increase until peaking in June with $20.5 \%$; after a gradual decline to return eventually to lower values in August with a cumulative incidence of abortion of $2.4 \%$ (Figure 2).

The cumulative incidence of abortion was higher in cattle with 3-6 years of age group (17.60\%) than those $>6$ years age group $(10.50 \%)$. The odds of abortion in younger cattle were 1.81-times higher than older cattle. There was a significant difference $(P<0.05)$ in the cumulative incidence of abortion between age groups. A crossbreed cattle had almost three times odds $(\mathrm{OR}=2.6)$ of abortion as compared to local breed. The difference in cumulative incidence of abortion between the two breeds was statistically significant $(P<0.05)$. The cumulative incidence of abortion in monoparous cattle was higher than that of pluriparous cattle with significant difference $(\mathrm{OR}=1.7 ; \quad P<0.05)$. Similarly, the higher cumulative incidence of abortion $(29.80 \%)$ was recorded in cattle that had a previous history of abortion than those who did not have a previous history of abortion $(8.90 \%)$ with a statistically significant difference $(\mathrm{OR}=4.36 ; P<0.05)$, as described in Table 3 .

The statistically significant difference was observed between cumulative incidence of abortion and management system $(P<0.05)$. The cattle managed under semi-intensive management system had twice the odds $(\mathrm{OR}=2.18)$ of abortion compared to those kept under the extensive management system. Concerning the breeding system of cattle, the cumulative incidence of abortion was higher in cattle $(16.80 \%)$ bred by natural service than those bred by artificial insemination (AI) $(9.00 \%)$. Cattle bred by natural service 


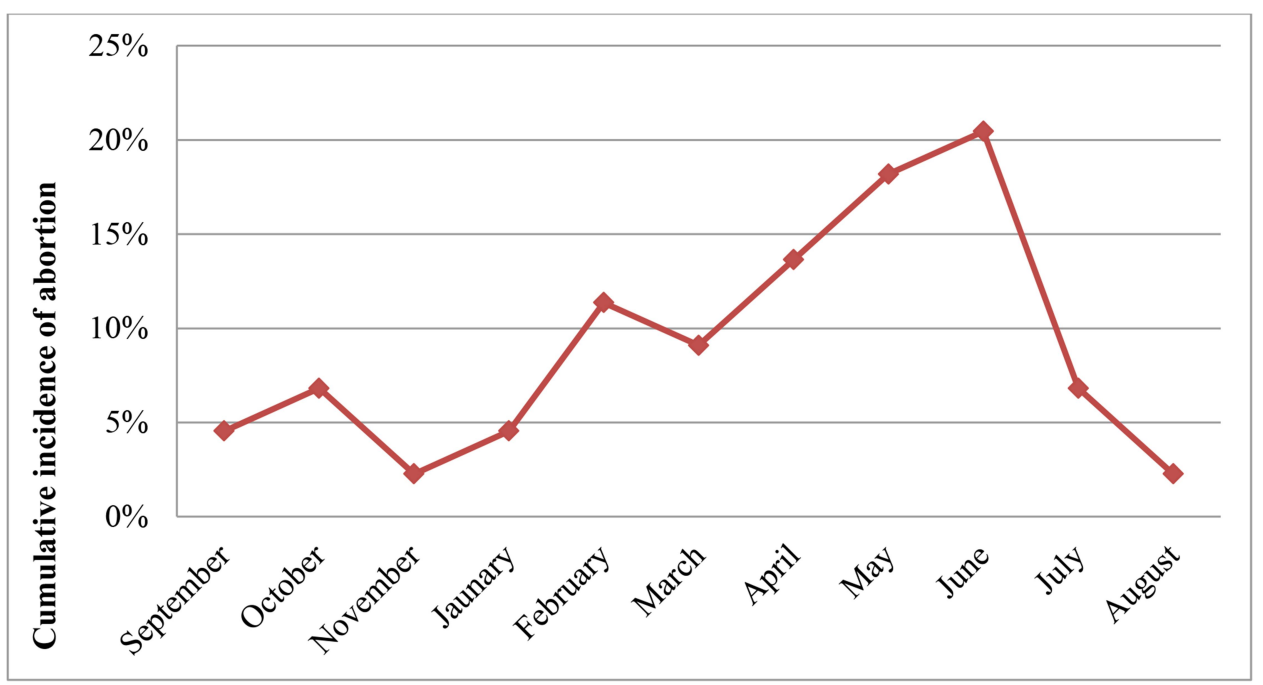

Figure 2 Cumulative incidence of cattle abortion by month in the study areas.

had 2-times $(\mathrm{OR}=2.04 ; P<0.05)$ greater odds of abortion than those bred by AI. Cattle that were exposed to dogs had a higher $(23.80 \%)$ cumulative incidence of abortion than those not exposed $(12.40 \%)$, and the difference was statistically significant $(\mathrm{OR}=2.21 ; P<0.05)$. Regarding the season, the highest (35.60\%) and lowest (5.60) cumulative incidence of abortion were recorded in autumn and summer, respectively. This difference in cumulative incidence of abortion among the seasons was statistically significant $(P<0.05)$. Out of a total 484 sampled pregnant cattle, $5.17 \%(\mathrm{n}=25)$ of pregnant cattle were tested positive on screening using RBPT. Further, confirmation using CFT identified an overall seroprevalence $4.55 \%(\mathrm{n}=22)$ of Brucella antibodies positive cattle. The higher cumulative incidence of abortion (31.82\%) was observed in Brucella antibody positive cattle than Brucella antibody negative cattle (13.42\%), with a statistically significant difference $(P<0.05)$. However, the cattle abortion was not associated with independent variables like the study districts, agro-ecology, introduction of new cattle, or herd size (Table 4).

The variables with a $P$-value less than or equal to 0.25 in univariable with no multicollinearity were entered in the multivariable logistic regression model. No significant interactions between variables were detected. The HosmerLemeshow goodness-of-fit test showed that the model fitted the data well $(P=0.20)$. The multivariable logistic

Table 3 Univariable Logistic Regression Analysis of Host-Related Abortion Risk Factors in the Study Areas

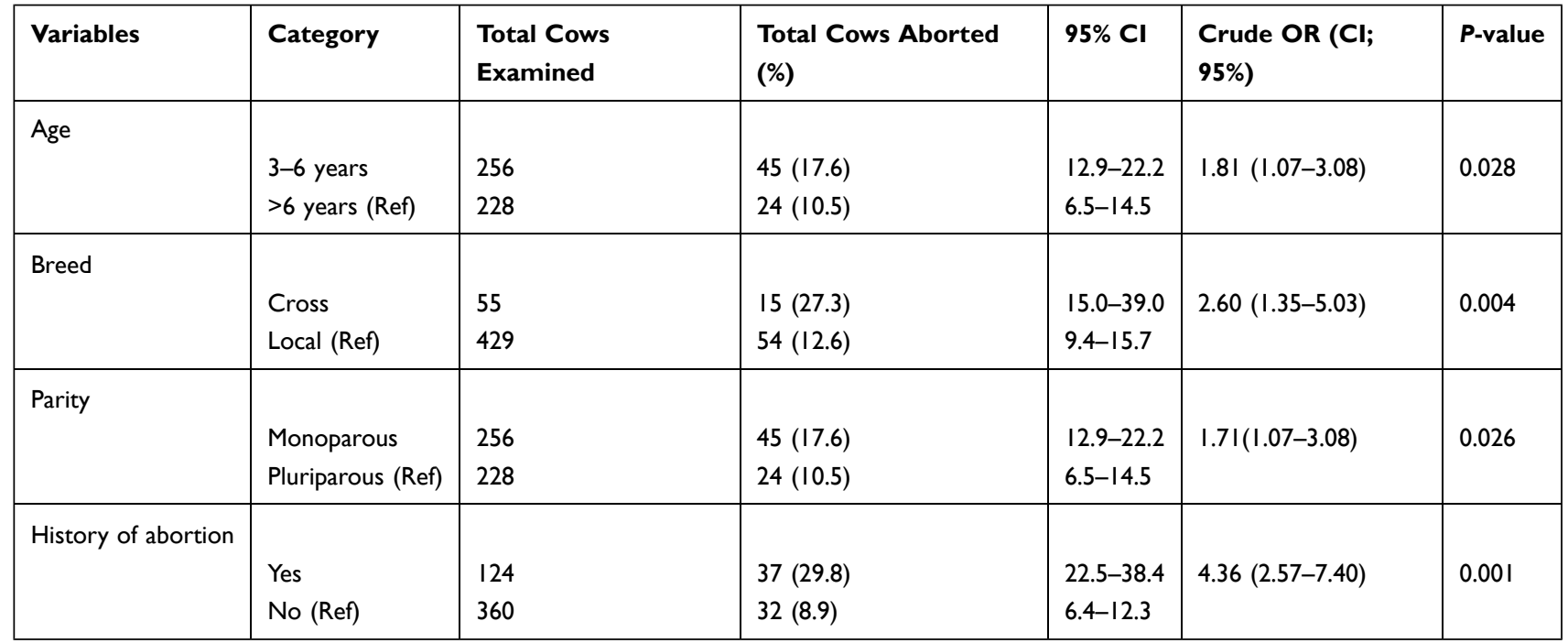

Abbreviations: $\mathrm{OR}$, odds ratio; $\mathrm{Cl}$, confidence interval; Ref, reference. 
regression model showed that crossbred cattle had higher odds $(\mathrm{OR}=4.07, P<0.05)$ of abortion compared to local breeds. Similarly, this study also showed that cattle from a large herd size had higher odds $(\mathrm{OR}=2.87, P<0.05)$ of abortion than those from small herd sizes. Cattle which were exposed to dogs had an almost 2-times $(\mathrm{OR}=2.27$, $P<0.05)$ more odds of abortion than those not exposed to a dog. Moreover, this model also showed that cattle calving in the autumn season was almost three times $(\mathrm{OR}=2.87, P<0.05)$ more likely to had abortion comparing to the winter season. The cattle that had a previous history of abortion was 3.47-times the odds $(\mathrm{OR}=3.47, P<0.05)$ of abortion than those that had no previous history of abortion. The odds of abortion were 3.11-times ( $\mathrm{OR}=3.11$, $P<0.05$ ) for cattle bred by natural service (Table 5).

\section{Discussion}

In the present study, an overall $14.30 \%$ cumulative incidence of cattle abortion was recorded. This finding is in line with previous reports, ${ }^{36,37}$ which reported $14.60 \%$ and $13.90 \%$ cumulative incidence of cattle abortion in Assella and Bedelle, respectively. Comparable levels of

Table 4 Univariable Logistic Regression Analysis of Managemental and Environmental-Related Risk Factors of Abortion in Cows in the Study Areas

\begin{tabular}{|c|c|c|c|c|c|c|}
\hline Variables & Category & $\begin{array}{l}\text { Total Cows } \\
\text { Examined }\end{array}$ & $\begin{array}{l}\text { Total Cows } \\
\text { Aborted (\%) }\end{array}$ & $95 \% \mathrm{Cl}$ & $\begin{array}{l}\text { Crude OR (Cl; } \\
95 \%)\end{array}$ & $P$-value \\
\hline \multirow[t]{3}{*}{ District } & & & & & & \\
\hline & Limu Seka & 301 & $43(14.3)$ & $10.8-18.7$ & $1.0(0.58-1.68)$ & 0.981 \\
\hline & Chora Boter (Ref) & 183 & $26(14.2)$ & $9.9-20.0$ & & \\
\hline \multirow[t]{3}{*}{ Agro-Ecology } & & & & & & \\
\hline & Lowland & 99 & II (II.I) & $6.3-18.8$ & I.42 (0.7I-2.82) & 0.318 \\
\hline & Mid-altitude (Ref) & 385 & $58(15.1)$ & $11.8-19.0$ & & \\
\hline \multirow[t]{4}{*}{ Herd size } & & & & & & 0.179 \\
\hline & Large & 225 & $38(16.9)$ & $|2.0-2| .8$ & $1.80(0.97-3.36)$ & 0.064 \\
\hline & Medium & 101 & $15(14.9)$ & $7.9-21.8$ & I.I7 (0.6I-2.23) & 0.645 \\
\hline & Small Ref) & 158 & $16(10.1)$ & $5.4-14.8$ & & \\
\hline \multirow[t]{3}{*}{ Management system } & & & & & & \\
\hline & Semi-intensive & 61 & $15(24.6)$ & 13.8-35.4 & $2.18(1.14-4.16)$ & 0.019 \\
\hline & Extensive (Ref) & 423 & $54(12.8)$ & $9.6-15.9$ & & \\
\hline \multirow[t]{3}{*}{ Type of breeding } & & & & & & \\
\hline & Natural & 328 & $55(16.8)$ & $12.7-20.8$ & $2.04(1.10-3.80)$ & 0.024 \\
\hline & Al Ref) & 156 & $14(9.0)$ & $4.5-13.5$ & & \\
\hline \multirow[t]{3}{*}{ Contact of cows with dogs } & & & & & & \\
\hline & Yes & 80 & $19(23.8)$ & |4.4-33.I & $2.21(1.22-3.99)$ & 0.009 \\
\hline & No (Ref) & 404 & $50(12.4)$ & $9.2-15.6$ & & \\
\hline \multirow[t]{3}{*}{ Introduction of new animals } & & & & & & \\
\hline & Yes & 31 & $7(22.6)$ & $7.9-37.3$ & I.84 (0.76-4.45) & 0.176 \\
\hline & No (Ref) & 453 & $62(13.7)$ & $10.5-16.9$ & & \\
\hline \multirow[t]{5}{*}{ Season } & & & & & & 0.001 \\
\hline & Autumn & 87 & $31(35.6)$ & $25.6-45.7$ & $2.09(0.88-4.96)$ & 0.033 \\
\hline & Summer & 231 & $13(5.6)$ & $2.7-8.6$ & $4.26(1.92-9.46)$ & 0.001 \\
\hline & Spring & 92 & $10(10.9)$ & $4.5-17.2$ & $0.46(0.22-0.94)$ & 0.097 \\
\hline & Winter (Ref) & 74 & $15(20.3)$ & II.I-29.4 & & \\
\hline \multirow[t]{3}{*}{ Brucellosis status } & & & & & & \\
\hline & Positive & 22 & 7 (3I.82) & $|2.36-5| .28$ & $0.33(0.13-0.85)$ & 0.021 \\
\hline & Negative (Ref) & 462 & $62(13.42)$ & $10.31-16.53$ & & \\
\hline
\end{tabular}

Abbreviations: OR, odds ratio; $\mathrm{Cl}$, confidence interval; Ref, reference; $\mathrm{Al}$, artificial insemination. 
Table 5 Multivariable Logistic Regression Analysis of Potential Risk Factors of Abortion in Cows in Study Areas

\begin{tabular}{|c|c|c|c|c|}
\hline Factors & Number of Cows Examined & Aborted Cows (\%) & Adjusted OR (95\% Cl) & $P$-value \\
\hline \multicolumn{5}{|l|}{ Breed } \\
\hline Cross & 55 & $15(27.3)$ & $4.07(1.74-9.52)$ & 0.001 \\
\hline Local (Ref) & 429 & $54(12.6)$ & & \\
\hline Herd size & & & & 0.026 \\
\hline Large & 225 & $38(16.9)$ & $2.79(1.32-5.87)$ & 0.007 \\
\hline Medium & 101 & $15(14.9)$ & $1.38(0.62-2.93)$ & 0.405 \\
\hline Small (Ref) & 158 & $16(10.1)$ & & \\
\hline Season & & & & 0.001 \\
\hline Autumn & 87 & $31(35.6)$ & $2.87(1.20-6.90)$ & 0.018 \\
\hline Summer & 231 & $13(5.6)$ & $0.44(0.20-0.97)$ & 0.042 \\
\hline Spring & 92 & $10(10.9)$ & $1.58(0.62-4.02)$ & 0.342 \\
\hline Winter (Ref) & 74 & $15(20.3)$ & & \\
\hline \multicolumn{5}{|l|}{ Previous history of abortion } \\
\hline Yes & 124 & $37(29.8)$ & $3.47(1.84-6.53)$ & 0.001 \\
\hline No (Ref) & 360 & $32(8.9)$ & & \\
\hline \multicolumn{5}{|l|}{ Type of breeding } \\
\hline Natural & 328 & $55(16.8)$ & $3.11(1.4 I-6.84)$ & 0.005 \\
\hline Al (Ref) & 156 & $14(9.0)$ & & \\
\hline \multicolumn{5}{|l|}{ Contact of cows with dog } \\
\hline Yes & 80 & $19(23.8)$ & $2.27(1.13-4.55)$ & 0.021 \\
\hline No (Ref) & 404 & $50(12.4)$ & & \\
\hline
\end{tabular}

Abbreviations: $\mathrm{OR}$, odds ratio; $\mathrm{Cl}$, confidence interval; Ref, reference; $\mathrm{Al}$, artificial insemination.

cumulative incidences were also reported by Benti and Zewdie $^{8}(12.20 \%)$ in Borena zone and Regassa and Ashebir $^{12}$ (13.30\%) in Mekelle city. However, the cumulative incidence of cattle abortion reported in the current study was higher than the values reported in Bako $(6.0 \%),{ }^{38}$ in selected sites of Arsi zone $(8.70 \%)^{39}$ in Kombolcha town $(9.10 \%),{ }^{20}$ in Bishoftu town in East Shoa $(5.30 \%),{ }^{23}$ in urban and peri-urban areas of Hosanna $(5.90 \%),{ }^{40}$ in Wollega zone $(4.40 \%),{ }^{41}$ and in Jimma town, Ethiopia (1\%). ${ }^{42}$ On the other hand, this result is lower than the values (19.70\%) reported in Gondar $^{43} ; 28.90 \%$ in Adeaberga ${ }^{21}$ in western Ethiopia; and $54.50 \%$ reported in Kersa district, Jimma zone. ${ }^{44}$ This result is also lower than values $(57.10 \%)$ reported from Sudan. ${ }^{45}$ This variation in the cumulative incidence of cattle abortion might be due to differences in environmental factors, management systems, and levels of veterinary service.

The current study indicated that the highest cumulative incidence of abortion was observed over the last third gestation stage, and the incidence was increased with the stage of pregnancy. This might be due to the difficult diagnosis of abortion during the first third stage and some causes of abortion in cattle were gestation stagespecific. ${ }^{16}$ In addition, abortion usually caused by brucellosis and leptospirosis occurs in the third trimester. ${ }^{5,11,46}$ This is in agreement with previous studies in Ethiopia $^{8,36,37,47}$ and elsewhere, ${ }^{48}$ which reported that most of the abortion cases occurred in the third trimester. This result is different from the reports of Thurmond et al ${ }^{18}$ and Hanson et $\mathrm{al}^{49}{ }^{49}$ who reported that the highest risk of abortion occurred in the second trimester. This might be due to differences in environmental factors, breed, and management systems in the study areas.

The highest and lowest cumulative incidence of abortion were recorded in June $(20.50 \%)$ and November $(2.30 \%)$, respectively. This might be because temperature and humidity are more likely to affect the spread of infectious agents, and heat stress also could cause abortion in cattle. This finding is in agreement with previous studies, ${ }^{19,48}$ where the highest cumulative incidence of abortion occurred in June, and abortion rates increase from May to August and decrease from October to February. The observed difference of the reports could be 
attributed to factors including agro-ecology, breed types, and management systems.

A statistically significant difference was observed between the occurrence of abortion and cattle breed $(P<0.05)$ with crossbreed cattle having a 4.07-times higher risk of abortion than the local breed. This might be because crossbreeds were less adapted to the tropical conditions of high temperature and humidity, disease, and low feed quality than local breeds, making them more susceptible than local breeds. ${ }^{50}$ This finding is in line with previous studies ${ }^{20,22}$ in which the reported breed significantly affected the occurrence of abortion in cattle. Similar to this result, others ${ }^{51,52}$ also detected the significant effect of breed on the incidence of abortion in cattle in Nigeria and India, respectively. However, different from this result, some studies ${ }^{40,42,53}$ reported that a breed of cattle was not significantly associated with the occurrence of abortion. The difference in the results could be related to the production system and environmental conditions that might have appeared in the different study areas.

This result revealed that the risk of abortion was significantly $(P<0.05)$ different between studied herds with larger herd sizes having almost three times $(\mathrm{OR}=2.79)$ the odds to have abortion than small herd sizes. This may be due to an increase in herd size usually being accompanied by an increase in stocking density, one of the determinants for exposure to infection caused by abortion, especially following abortion or calving. ${ }^{54}$ In agreement with our finding, studies ${ }^{17,55}$ have reported that herd size was significantly influenced by the incidence of cattle abortion in Iran. Different from this, Haile et $\mathrm{al}^{40}$ indicated that the risk of abortion was independent of herd size in smallholder farms from Addis Ababa, Ethiopia. Similarly, other studies ${ }^{56,57}$ also stated herd size was not a risk factor for the incidence of abortion in Korea and Poland, respectively. The difference in these results may be due to environmental factors, breed of cattle, and management system.

A statistically significant difference $(P<0.05)$ was observed between abortion and seasons. Cattle had an almost 3-times higher ( $\mathrm{OR}=2.87)$ odds of abortion in spring season (March, April, and May) compared to winter season (December, January, and February). This might be due to seasonal changes that may reflect changing exposure to infectious disease agents, a changing pattern of endocrine function, the presence of a seasonal vector, or various seasonal feeding regimens. ${ }^{58,59}$ This result is in agreement with several reports from other countries. ${ }^{17,48,51,55}$ However, reports in Korea, Iran, and Chile differ from this finding, ${ }^{52,56,60,61}$ reporting the season of calving did not affect the incidence of abortion. This difference may be due to the variation in environmental conditions, breed of cattle, and management system.

A cow that had a previous history of abortion had almost 4-times higher $(\mathrm{OR}=3.47)$ odds of abortion than those with no previous history of abortion. This might be due to repeated abortion being expected in neosporosis, listeriosis, and leptospirosis. ${ }^{32,62}$ This finding is in line with previous reports ${ }^{17,18,55}$ which identified cattle that had a previous history of abortion as a risk factor for abortion occurrence in the next pregnancy.

The present study shows that the type of breeding used was significantly associated with the incidence of abortion $(P<0.05)$ and cows bred by natural service were 3-times $(\mathrm{OR}=3.11)$ more likely to face abortion compared to those bred by artificial insemination (AI). This may be due to transmission of disease during service from an infected bull to the female being more common in natural mating than AI. A study in Tigray ${ }^{12}$ has also shown that higher incidence of abortion was recorded in cattle bred by natural service than those bred by AI.

Similarly, this result shows that the risk of abortion was 2-times higher in cows which had contact with a dog compared to those that not have contact with a dog $(\mathrm{OR}=2.3)$. This may be due to dogs being the definitive host of Neospora caninum and cows being among the intermediate hosts. Cows become infected by ingestion of feed and water contaminated by oocysts shed in dog feces. ${ }^{63,64}$ This finding is consistent with some previous studies in Ethiopia ${ }^{65,66}$ and elsewhere, ${ }^{67,68}$ which reported that neosporosis was significantly associated with the occurrence of abortion in cows which had contact with dogs. This result also agrees with the report of, Bahari et al, ${ }^{69}$ who reported that cows had frequent contact with dogs that experienced leptospiral abortion. This may be due to leptospiral abortion (canicola infection) occuring in the area where dogs act as the main reservoir. Moreover, cross-infection might occur between cows and dogs, and cows may play a role in the maintenance of canicola serovar in nature. ${ }^{70} \mathrm{~A}$ cattle contact with stray dogs was a higher risk of abortion due to brucellosis. ${ }^{71}$ Because dogs were spreading the disease by dragging dead or aborted calves and after birth between neighboring herds. $^{72}$

In the present study, no statistically significant difference $(P>0.05)$ was observed between Brucella antibody 
positive and negative cattle. This indicated that brucellosis may not be associated with abortion in cattle in study areas. This could be true as abortion in cattle has multiple causes, infectious (Neospora caninum, Leptospira spp, Listeria spp, Coxiella burnetti) and non-infectious (heat stress, nutritional deficiencies, trauma, toxic substances, etc) other than brucellosis. This finding is in agreement with previous reports from central, southern, and western part of Ethiopia. ${ }^{65,66,73}$ A study in Pakistan ${ }^{74}$ also reported that the Brucella antibody positive cattle were not associated with abortion in cattle.

\section{Conclusion}

In the present study, the cumulative incidence of abortion was high, indicating that abortion was one of the significant causes of cattle production loss in study areas. The study indicated that abortion in cattle depends on breed, herd size, breeding methods, previous history of abortion, close-contact between cow and dogs, and season. The current study also showed that higher abortion was observed in Brucella antibody positive than negative cattle. However, no significant difference was observed. Hence, it is important to create awareness about the impact of the abortion on cattle production and the applicable control technique of abortion should be aimed and implemented. Further investigation considering more causes should be carried out to identify the specific cause of abortion and the associated loss in the study areas.

\section{Ethics Statement}

All procedures were conducted according to the experiment practice and standards approved by the animals' welfare and research ethic committee at Jimma University School of Veterinary medicine, college of Agriculture, and Veterinary medicine that is following the international guidelines for animal welfare with $\mathrm{AgVmVM} / 16 / 1$ reference number. As well, verbal consent was obtained from the owner of the animals. Full cooperation and voluntary participation of all participants was obtained by assuring them the confidentiality of their involvement.

\section{Acknowledgments}

The authors would like to thank Jimma University college of Agriculture and veterinary Medicine, and Ethiopian Institute of Agricultural Research for their assistance and cooperation during this study. They also thank the farmers who participates in this study. Moreover, the authors are grateful to the Jimma zone office for their kind help and facilitation during the field work.

\section{Disclosure}

Funding support proving by Jimma University College of Agriculture and Veterinary Medicine. No addition grant support was used for this study. The authors declare that they have no other potential conflicts of interest for this work.

\section{References}

1. CSA. Livestock and Livestock Characteristics, Agricultural sample Survey. Addis Ababa, Ethiopia. Statistical Bulletin. 2017;2(583):9-13.

2. Zegeye Y. Challenges and opportunities of livestock marketing in Ethiopia. In: proceedings of the 10th annual conference of Ethiopian Society of Animal Production (ESAP), 22-24 August 2002 held in Addis Ababa, Ethiopia. Int J Adv Res Biol Sci. 2003;7:47-54.

3. Tulu D, Gebeyehu S. Prevalence of Major Reproductive Problem and Associated Risk Factor in Dairy Cattle of Jimma Horro District in Kelem Wollega Zone, Western Ethiopia. Int J Res Agr Sci. 2018;5(5):2348-3997.

4. Jergefa T, Kelay B, Bekana M, Teshale S, Gustafson H, Kindahl H. Epidemiological study of bovine brucellosis in three agro-ecological areas of central Oromiya, Ethiopia. Rev Sci Tech Office Int Des Epizooties. 2009;28(3):933-943. doi:10.20506/rst.28.3.1939

5. Tulu D, Deresa B, Begna F, Gojam A. Review of common causes of abortion in dairy cattle in Ethiopia. $J$ Veterinary Med Animal Health. 2018;10(1):1-13. doi:10.5897/JVMAH2017.0639

6. Dessalegn G, Berhan T, Gebreyohannes B. Study of Reproductive and Production Performance of Cross Breed Dairy Cattle under Smallholders Management System in Bishoftu and Akaki Towns. Int J Adv Res Biol Sci. 2016;3(2):151-157.

7. Adane H, Yisehak T, Niguse T. Assessment of major reproductive disorders of dairy cattle in urban and per urban area of Hosanna, Southern Ethiopia. Animal Veterinary Sci. 2014;2(5):135-141. doi:10.11648/j.avs.20140205.11

8. Benti AD, Zewdie W. Major reproductive health problems of indigenous Borena cows in Ethiopia. $J$ Adv Veterinary Animal Res. 2014;1(4):182-188. doi:10.5455/javar.2014.a32

9. Peter AT. Abortions in dairy cows: new insights and economic impact. Adv Dairy Tech. 2000;12:233.

10. Hossein-Zadeh GN. Effects of main reproductive and health problems on the performance of dairy cows: A review. Spanish J Agr Res. 2013;11(3):718-735. doi:10.5424/sjar/2013113-4140

11. Parthiban S, Malmarugan S, Murugan MS, Johnson Rajeswar J, Pothiappan P. Review on Emerging and Reemerging Microbial Causes in Bovine Abortion. Int J Nutr Food Sci. 2015;4(4):1-6. doi:10.11648/j.ijnfs.s.2015040401.11

12. Regassa T, Ashebir G. Major Factors Influencing the Reproductive Performance of Dairy Farms in Mekelle City, Tigray, Ethiopia. J Dairy Veterinary Animal Res. 2016;3(4):88.

13. Pal M, Lemu D, Worku S, Sero-prevalence DG. Study of Bovine Brucellosis and Reproductive Problems in Small-scale Dairy Farms of North Shewa, Ethiopia. Int J Livestock Res. 2016;6(9):1-10. doi:10.5455/ijlr.20160922081855

14. OIE. Manual of diagnostic tests and vaccines for terrestrial animals. World Org Animal Health. 2009;2:5-35.

15. FAO. Brucella Melitensis in Eurasia and the Middle East. Rome: FAO Animal Production and Health Proceedings; 2010:10.

16. Radostits OM, Gay CC, Hinchcliff KW, Constable PD, Medicine V. A Text Book of Diseases of Cattle, Sheep, Pigs, Goats and Horses, 10th Ed. W.B., Saunders. London; 2007:963-985. 
17. Keshavarzi H, Sadeghi-Sefidmazgi A, Ringgaard Kristensen A, Helena Stygar A. Abortion studies in Iranian dairy herds: I. Risk Factors Abortion Livestock Sci. 2017;195:45-52. doi:10.1016/j. livsci.2016.11.004

18. Thurmond MC, Branscum AJ, Johnson WO, Bedrick EJ, Hanson TE. Predicting the probability of abortion in dairy cows: a hierarchical Bayesian logistic-survival model using sequential pregnancy data. Prev Vet Med. 2005;68(2-4):223-239. doi:10.1016/j.prevetmed.2005.01.008

19. Carpenter TE, Chriel M, Andersen M, et al. An epidemiologic study of late-term abortions in dairy cattle in Denmark. Prev Vet Med. 2006;77(3-4):215-229. doi:10.1016/j.prevetmed.2006.07.005

20. Tesfaye D, Shamble A. Reproductive health problems of cows under different management systems in Kombolcha, Northeast Ethiopia. Adv Biol Res (Rennes). 2013;7(3):104-108.

21. Siyoum T, Yohannes A, Shiferaw Y, Asefa Z, Eshete M. Major reproductive disorders on Jersey breed dairy cattle at Adea Berga dairy farm, West Shewa Zone, Oromia Region, Ethiopia. Ethiopian Veterinary J. 2016;20(1):91-103. doi:10.4314/evj.v20i1.7

22. Gizaw M, Bekana M, Abayneh T. Major reproductive health problems in smallholder dairy production in and around Nazareth town, Central Ethiopia. J Veterinary Med Animal Health. 2007;5 (4):112-115.

23. Eshete G, Moges N. Major reproductive health disorders in cross breed dairy cows in Ada'a District, East Shoa, Ethiopia. Global Veterinary. 2014;13(4):444-449.

24. Megersa B, Biffa D, Abunna F, Regassa A, Godfroidand J, Skjerve E. Seroprevalence of brucellosis and its contribution to abortion in cattle, camel, and goat kept under pastoral management in Borana, Ethiopia. Trop Anim Health Prod. 2011;43(3):651-656. doi:10.1007/ s11250-010-9748-2

25. Minda AG, Gobena A, Tesfu K, Getachew T, Angella A, Gezahegne MK. Seropositivity and risk factors for Brucella in dairy cows in Asella and Bishoftu towns, Oromia Regional State, Ethiopia. Af J Microbiol Res. 2016;10(7):203-213. doi:10.5897/AJMR2015.7707

26. Tsegaye Y, Kyule M, Fikre Lobago F. Seroprevalence and Risk Factors of Bovine Brucellosis in Arsi Zone, Oromia Regional State, Ethiopia. Am Sci Res J Eng Tech Sci. 2016;24(1):16-25.

27. Thrusfield M.Veterinary Epidemiology. 3rd Vol. (2005). Blackwell Publishing, England;2005.345-543.

28. Richard W. Dairying. Tropical Agriculturalist. 1st. Macmillan Press London. 1993. 43-48.

29. Wathes D, Brickell J, Bourne N, Swali A, Cheng Z. Factors influencing heifer survival and fertility. J Anim Sci. 2008;2(8):1135-1143.

30. Tolosa T, Regassa F, Belihu K. Seroprevalence Study of Bovine Brucellosis in Extensive Management System in Selected Sites of Jimma Zone, Western Ethiopia. Bulletin Animal Health Production Africa. 2008;56(1):25-37. doi:10.4314/bahpa.v56i1.32823

31. Asgedom H, Damena D, Duguma R. Seroprevalence of bovine brucellosis and associated risk factors in and around Alage district, Ethiopia. SpringerPlus. 2016;5(851):1-8. doi:10.1186/s40064-0162547-0

32. Markusfeld NO. Epidemiology of bovine abortions in Israeli dairy herds. Prev Vet Med. 1997;31(3-4):245-255. doi:10.1016/S01675877(96)01142-7

33. Ibrahim N, Belihu K, Lobago F, Bekana M. Sero-prevalence of bovine brucellosis and its risk factors in Jimma zone of Oromia Region, South-western Ethiopia. Trop Anim Health Prod. 2010;42 (1):35-40. doi:10.1007/s11250-009-9382-z

34. OIE. Bovine Brucellosis. Manual of Diagnostic Tests and Vaccines for Terrestrial Animals. 5th ed. Paris: Office International des Epizootics; 2004:409-438.

35. Dohoo I, Martin W, Stryhn H. Veterinary Epidemiologic Research. 2nd ed. Prince Edward Island: AVC, Charlottetown; 2009:239-249.

36. Dinka H. Reproductive performance of crossbred dairy cows under smallholder conditions in Ethiopia. J Veterinary Med Animal Health. 2013;1(5):101-103.
37. Bitew M, Prased S. Study on major reproductive health problems in indigenous and cross breed cow in and around Bedelle, South west Ethiopia. J Animal Veterinary Adv. 2011;10(6):723-727. doi:10.3923/ javaa.2011.723.727

38. Haftu B, Gashaw A. Major Reproductive Health Problems of Dairy Cows in and around Bako, West Ethiopia. Ethiopian J Animal Production. 2009;9(1):89-98.

39. Degefa T, Duressa A, Duguma R. Brucellosis and some reproductive problems of indigenous Arsi cattle in selected Arsi zones of Oromia Regional State, Ethiopia. Global Veterinary. 2011;7:45-53.

40. Haile A, Kassa T, Mihret M, Asfaw Y. Major Reproductive Disorders in Crossbred Dairy Cows under Small holding in Addis Ababa Milk shed, Ethiopia. World J Agr Sci. 2010;6:412-418.

41. Wagari A, Shiferaw J. Major Reproductive Health Problems of Dairy Cows at Horro Guduru Animal Breeding and Research Center, Horro Guduru Wollega Zone, Ethiopia. Int J Biochem Biophys Mol Biol. 2016;1(1):18-24.

42. Gashaw A, Worku F, Mulugeta S. Assessment of smallholder dairy production and their reproductive health problems in Jimma Town, South-Western Ethiopia. Int $J$ Applied Basic Med Res. 2011;9:80-86.

43. Kifle M, Moges N. Major Reproductive Health Disorders of Cow in and Around Gondar, North West Ethiopia. J Reproduct Infertility. 2016;7(3):88-93.

44. Ebrahim F, Feyera T, Abera B. Major animal health constraints of market oriented livestock in Kersa Woreda, Southwest Ethiopia. $A d v$ Animal Veterinary Sci. 2016;4(2):92-98. doi:10.14737/journal.aavs/ 2016/4.2.92.98

45. Elhassan AM, Fadol MA, Elfahal AM, Elhussein AR. Cross sectional study on reproductive health disorders in dairy cattle in Sudan. $J A d v$ Veterinary Animal Res. 2015;2(2):101-106. doi:10.5455/javar.2015.b57

46. Yadeta W, Bashahun GM, Abdela N. Leptospirosis in Animal and its Public Health Implications: A Review. World Applied Sci J. 2016;34 (6):845-853.

47. Hadush A, Abdella A, Ragassa F. Major Prepartu and postpartum Reproductive problems of dairy cattle in central Ethiopia. $J$ Veterinary Med Animal Health. 2013;5:118-123.

48. Norman HD, Miller RH, Wright JR, Hutchison JL, Olson KM Factors associated with frequency of abortions recorded through Dairy Herd Improvement test plans. J Dairy Sci. 2012;95 (7):4074-4084. doi:10.3168/jds.2011-4998

49. Hanson T, Bedrick EJ, Johnson WO, Thurmond MC. A mixture model for bovine abortion and foetal survival. Stat Med. 2003;22 (10):1725-1739. doi:10.1002/sim. 1376

50. Fielding, Matthewman. Tropical Cattle Management In: Bovine medicine, Diseases and Husbandry of Cattle. 2nd ed. Oxford, UK: Blackwell publishing company; 2004:68-81.

51. Yakubu A, Awuje AD, Omeje JN. Comparison of multivariate logistic regression and classification tree to assess factors influencing prevalence of abortion in Nigerian cattle breeds. $J$ Animal Plant Sci. 2015;25(6):1520-1526.

52. Khan MH, Manoj K, Pramod S. Reproductive disorders in dairy cattle under semi-intensive system of rearing in North-Eastern India. Veterinary World. 2016;9(5):512-518. doi:10.14202/vetworld.2016.512-518

53. Tigabneh A, Fantahun S, Bihonegn T, Tesfaye W. Assessment of major Reproductive disorders of dairy cattle in Dessie and Kombolcha towns, South Wollo, North Eastern Ethiopia. Int $J$ Adv Res Biol Sci. 2017;4(7):89-96.

54. Crawford RP, Huber JD, Adams BS. Epidemiology and surveillance. In: Nielsen K, Duncan JR, editors. Animal Brucellosis. Florida: CRC Press Inc; 1990:131-148.

55. Rafati N, Mehrabani Y, Hanson TE. Risk factors for abortion in dairy cows from commercial Holstein dairy herds in the Tehran region. Prev Vet Med. 2010;96(3-4):170-178. doi:10.1016/j.prevetmed.20 10.05 .008 
56. Lee J, Kim HI. Pregnancy loss in dairy cows: the contributing factors, effect on reproductive performance and the economic impact. $J$ Vet Sci. 2007;8(3):283-288. doi:10.4142/jvs.2007.8.3.283

57. Baranski W. Zduńczyk S Janowski T. J Veterinary Sc. 2012;15 (4):735-739.

58. Hafez E, Hafez B. Reproduction in Farm Animals. 7th ed. Philadelphia: Lippincot Williams and Wilkins; 2000:269-271.

59. Ghorbani G, Asadi-Alamoti A. Developed Management of Dairy Cattle. first ed. Isfahan, Iran: Industrial Unit of Jahad; 2004:92-100.

60. Lopez-Gatius F, Pabón M, Almería S. Neospora caninum infection does not affect early pregnancy in dairy cattle. Theriogenology. 2004;62:606-613. doi:10.1016/j.theriogenology.2003.11.002

61. Gadicke P, Monti G. Factors related to the level of occurrence of bovine abortion in Chilean dairy herds. Prev Vet Med. 2013;110 (2):183-189. doi:10.1016/j.prevetmed.2012.11.022

62. Corbellini LG, Pescador CA, Frantz F, Wunder E, Steffen D, Smith DR. Diagnostic survey of bovine abortion with special reference to Neospora caninum infection: importance, repeated abortion and concurrent infection in aborted fetuses in Southern Brazil. Veterinary J. 2006;172:114-120. doi:10.1016/j.tvj1.2005.03.006

63. Hall CA, Reichel MP, Ellis JT. Performance characteristics and optimization of cut-off values of two enzyme-linked immunosorbent assays for the detection of antibodies to Neospora caninum in the serum of cattle. Vet Parasitol. 2006;140:61-68. doi:10.1016/j. vetpar.2006.03.016

64. Pan Y, Jansen GB, Duffield TF, et al. Genetic susceptibility to Neospora caninum infection in Holstein cattle in Ontario. J Dairy Sci. 2004;87(11):3967-3975. doi:10.3168/jds.S0022-0302(04)73 537-7

65. Asmare K, Regassa F, Robertson LJ, Martin AD, Skjerve E. Reproductive disorders in relation to Neospora caninum, Brucella spp. and bovine viral diarrhoea virus sero status in breeding and dairy farms of central and southern Ethiopia. Epidemiol Infect. 2012;(2012):1-9.
66. Asmare K. Neospora caninum versus Brucella spp. exposure among dairy cattle in Ethiopia: A case control study. Trop Anim Health Prod. 2014;(2014)(46):961-966. doi:10.1007/s11250-014-0599-0

67. Jenkins M, Baszler T, Bjorkman C, Schares G, Williams D. Diagnosis and seroepidemiology of Neospora caninum-associated bovine abortion. Int J Parasitol. 2002;32(5):631-636. doi:10.1016/ S0020-7519(01)00363-0

68. Reichel MP, Alejandra AM, Gondim LF, Ellis JT. What is the global economic impact of Neospora caninum in cattle the billion dollar question. Int $J$ Parasitol. 2013;43:133-142. doi:10.1016/j.ijpara. 2012.10.022

69. Bahari A, Abdollahpour G, Sadeghi-Nasab A, Sattari Tabrizi S, Yavari M, Dadmehr B. A serological survey on leptospirosis in aborted dairy cattle in industrial farms of Hamedan suburb, Iran. Iranian J Veterinary Res. 2011;12(4):1-3.

70. Abdollahpour G, Shafighi ST, Tabrizi S. Serodiagnosis of leptospirosis in cattle in North of Iran. Gilan Iranian $J$ Veterinary Res. 2009;3:7-10.

71. Soomro AH, Kamboh AA, Rind R, et al. A study on prevalence and risk factors of brucellosis in cattle and buffaloes in district Hyderabad, Pakistan. J Animal Health Product. 2014;2(3):33-37. doi:10.14737/journal.jahp/2014/2.3.33.37

72. Richey EJ, Harrell CD. Brucella abortus disease (Brucellosis) in beef cattle. University of Florida. Cooperative Extension Services. Inst Food Agr Sci. 1997;100:1-6.

73. Kebede T, Ejeta G, Ameni G. Seroprevalence of bovine brucellosis in smallholder farms in central Ethiopia (Wuchale-Jida district). Rev Med Vet (Toulouse). 2008;159(1):3-9.

74. Shabbir MZ, Khalid RK, Freitas DM, et al. Serological evidence of selected abortifacients in a dairy herd with history of abortion. Pakistan Veterinary J. 2013;33(1):19-22.

\section{Publish your work in this journal}

Veterinary Medicine: Research and Reports is an international, peerreviewed, open access journal publishing original research, case reports, editorials, reviews and commentaries on all areas of veterinary medicine. The manuscript management system is completely online and includes a very quick and fair peer-review system. Visit http://www.dovepress.com/testimonials.php to read real quotes from published authors. 